\title{
Preussisches Baupolizeirecht.
}

Unter bejonderer Berüdffithtigung

der Baupolizeioronung für den Stadtfreis Berlin

vom 15. 2uguit 1897

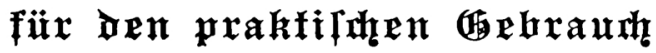

Dargeftellt

yoì

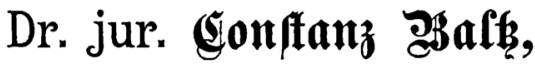

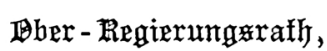

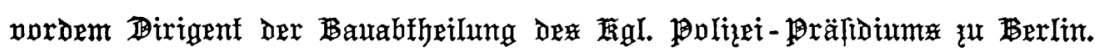

Bweite vermehrte und verbefferte $\mathfrak{A}$ uflage.

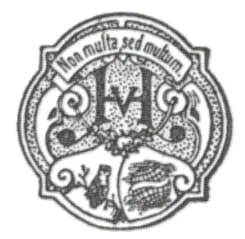

Berlin.

1. 五. 1900. 
